\title{
Non-Edible Moringa Oleifera Seeds for Environmentally Friendly Biodiesel - A Review
}

\author{
Miranti Nur Arafah ${ }^{1}$, Raden Sukmawati ${ }^{1}$, Hasna Mutiara Safitri ${ }^{1}$, Herawati Budiastuti ${ }^{* 2}$ \\ ${ }^{1,2}$ Politeknik Negeri Bandung, Bandung, Indonesia \\ Email: herabudi@polban.ac.id ${ }^{* 2}$
}

Received 03 Januari $2021 \mid$ Revised 10 Februari $2021 \mid$ Accepted 05 Maret 2021

\begin{abstract}
ABSTRAK
Ketersediaan bahan bakar fosil semakin lama semakin berkurang. Hal tersebut menyebabkan dibutuhkannya pengganti bahan bakar alternatif yaitu biodiesel. Minyak biji kelor memiliki potensi sebagai bahan baku pembuatan biodiesel, karena kandungan asam oleatnya yang tinggi yaitu 75,36 87,49\%. Penelitian ini bertujuan untuk mengkaji pembuatan biodiesel, penggunaan katalis heterogen serta pengaruh parameter operasi terhadap hasil dan kualitas biodiesel dari minyak biji kelor dengan metode studi literatur. Tahapan yang dilakukan dalam studi literatur ini adalah pengumpulan, pemisahan dan analisis artikel jurnal serta perumusan pembahasan dan kesimpulan. Pembuatan biodiesel minyak biji kelor dilakukan dengan beberapa tahapan proses, yaitu pengambilan minyak dari biji, proses esterifikasi-transesterifikasi dan pemurnian biodiesel. Parameter operasi yang paling berpengaruh dalam menghasilkan biodiesel minyak biji kelor adalah rasio molar metanol dan minyak, konsentrasi katalis, waktu reaksi dan temperatur reaksi. Penggunaan katalis heterogen mampu menghasilkan yield biodiesel minyak biji kelor yang tinggi yaitu rata-rata lebih besar dari 90\%. Biodiesel minyak biji kelor telah sesuai dengan standar nasional (SNI 7182 : 2015) dan internasional (ASTM D6751 dan EN 14214)
\end{abstract}

Kata Kunci: Biodisel Minyak Biji Kelor, Katalis Heterogen, Parameter Operasi, Karakteristik Biodiesel.

\begin{abstract}
The availability of fossil fuels is decreasing over time. This causes the need for an alternative fuel substitute, namely biodiesel. Moringa oleifera seeds are the raw material for making Moringa seed oil, used as raw material for making biodiesel. This is due to its high oleic acid contents, in the range of $75,36 \%-87,49 \%$ the objectives of this study are to observe the production of biodiesel from Moringa seed oil, the use of heterogeneous catalysts in the production of Moringa seed oil biodiesel, the effect of operating parameters on the yield and quality of biodiesel produced. Literature study was done in this research, including the collection of journal articles, separation and analysis of journal articles, as well as the formulation of discussions and conclusions. Based on this study, there are several stages in the production of Moringa seed oil biodiesel, namely extracting oil from the seeds, esterificationtransesterification, and refining of biodiesel. Operating parameters affect the manufacture of Moringa seed oil biodiesel. The most influential operating parameters are the molar ratio of methanol and oil, catalyst concentration, reaction time, and reaction temperature. The use of heterogeneous catalysts is able to produce a high yield of Moringa seed oil biodiesel, which is on average greater than $90 \%$. Moringa seed oil biodiesel complies with both national (SNI 7182: 2015) and international (ASTM D6751 and EN 14214) standardr.
\end{abstract}

Keywords: Moringa Seed Oil, Biodiesel, Heterogeneous Catalyst, Operating Parameters 


\section{INTRODUCTION}

Currently, diesel engines are widely used to support everyday human life, such as transportation, heavy equipment, and industrial equipment. The application of diesel engines mostly still uses petroleum-based fuels. In fact, the availability of petroleum-based fuels is decreasing over time. Therefore, it needs an alternative fuel to replace fossil fuels, one of which is biodiesel. Biodiesel is a monoalkyl ester from vegetable oils or animal fats. Palm oil is a food oil that is usually used in making biodiesel [1]. Palm oil, if used as a raw material in the manufacture of biodiesel, can compete with human food needs [2]. To overcome this problem and reduce the cost of biodiesel production, nonedible vegetable oil is used as a raw material for making biodiesel [3].

Moringa seed oil is one of the non-edible oils. The oil produced from Moringa seeds contains high oleic acid $(75,36-87,49 \%)$ so it is suitable to be used as raw material for making biodiesel [4]. Moringa oleifera L. is a plant that is easy to grow and spread in tropical and subtropical areas, for example in tropical regions such as Indonesia, on various types of soil and is resistant to drought [5]. One of the factors that influences biodiesel yield is the type of catalyst. Usually the catalyst used is an acid or alkaline homogeneous catalyst because of its high reaction rate and economic price and high biodiesel yield produced. The disadvantage of acid and alkaline homogeneous catalysts is that it makes it difficult to separate biodiesel at the end of the process. Therefore, the use of heterogeneous catalysts began to be used because the separation process was easy. The use of heterogeneous catalysts in the manufacture of Moringa seed oil biodiesel is still rarely used. The potential for using heterogeneous catalysts still needs to be studied more deeply to determine the yield and quality of the biodiesel.

The manufacture of biodiesel with inappropriate operating conditions can cause biodiesel yields that are not optimal, the quality of biodiesel is below standard, and the use of excess energy which results in large production costs. Therefore, this literature study focus on the potential use of heterogeneous catalysts, the impact of operating parameters on biodiesel yield and the quality of Moringa seed oil biodiesel in terms of its characteristics.

\subsection{Biodiesel}

Diesel oil is one of the fuels that has an important role in the Indonesian economy. Biodiesel is a clear burner diesel replacement fuel made from natural materials from renewable sources [6]. The use of the term "biodiesel" has received approval from the Department of Energy (DOE), Environmental Protection Agency (EPA), and the American Society of Testing Materials (ASTM). The advantages of biodiesel are non-toxic, biodegradable, has a low number of carbon dioxide $\left(\mathrm{CO}_{2}\right)$ emissions and sulfur gas, so it is an environmentally friendly fuel [7].

Biodiesel can be obtained through the triglyceride transesterification process and or the free fatty acid esterification process. The process used depends on the quality of vegetable oil as raw material for making biodiesel. The esterification process aims to reduce free fatty acid levels, while the transesterification process aims to convert triglycerides into methyl esters (biodiesel).

\subsection{Moringa Oleifera Seeds Oil}

Moringa Oleifera plant is used as a hedge plant but its utilization is less than optimal, usually the fruit is used as food, a coagulant in water purification processes, and it can also be used as biodiesel by utilizing its seeds [4]. Moringa seed oil is one of the raw materials for making methyl esters (biodiesel). Moringa seeds are a part of the moringa plant that has a high oil content of $35 \%$ with an oleic acid content of $72.2 \%$. An excellent unsaturated fatty acid for conversion to methyl esters is oleic acid [8]. The methods that can be used to obtain oil from moringa seeds are steam distillation, hydraulic press, maceration extraction, and soxhletation extraction. Soxhletation extraction is the most effective method in extracting oil from a sample of up to $99 \%$ [9]. 


\subsection{Esterification Reaction}

Esterification reaction is a reaction between free fatty acids and methanol to become methyl esters with the help of acid catalysts such as $\mathrm{H}_{2} \mathrm{SO}_{4}$ and $\mathrm{HCl}$ [10]. The advantage of using a homogeneous acid catalyst in the esterification reaction is its high selectivity and activity, but it is difficult to separate from the reaction mixture and is less stable at high temperatures [11]. The esterification process is carried out if the free fatty acid content in Moringa seed oil is above 3\% [12] or the acid level is above $4 \mathrm{mg} \mathrm{KOH/g} \mathrm{[13].} \mathrm{Decreasing} \mathrm{the} \mathrm{free} \mathrm{fatty} \mathrm{acid} \mathrm{content} \mathrm{by} \mathrm{the} \mathrm{esterification} \mathrm{process} \mathrm{is}$ needed to prevent the saponification reaction from occurring during the transesterification process using an alkaline catalyst [14]. The occurrence of soap formation can inhibit the separation between methyl esters and glycerol which results in the formation of emulsions during the biodiesel washing process. The reactions that occur in the esterification process are as follows [28].



\section{Transesterification Process}

Figure 1. Esterification Reaction

Transesterification is a reaction between triglycerides in oil and alcohol to become alkyl ester which produces a by-product in the form of glycerol [15]. Catalysts used for conventional transesterification processes usually are homogeneous alkaline catalysts, such as potassium hydroxide $(\mathrm{KOH})$, sodium hydroxide $(\mathrm{NaOH})$, potassium methoxide $\left(\mathrm{CH}_{3} \mathrm{OK}\right)$, and sodium methoxide $\left(\mathrm{CH}_{3} \mathrm{ONa}\right)$ [15]. The transesterification reaction of triglycerides to methyl esters is as follows [28].

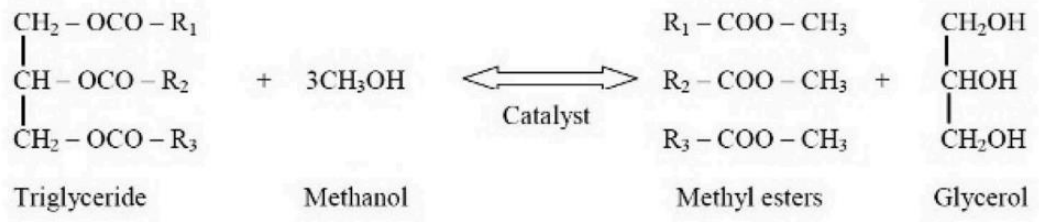

Figure 2. Transesterification Reactions

\subsection{Biodiesel Quality Standard by SNI 7182:2015}

Standards for biodiesel quality in Indonesia have been issued by National Standardization Body in the form of Indonesian National Standard or in Indonesian Standar Nasional Indonesia (SNI 7182: 2015). Indonesian biodiesel quality standards are shown in Table 1

Table 1. Standards of biodiesel quality based on SNI 7182:2015 [14]

\begin{tabular}{ccc}
\hline No & Parameters & Requirements \\
\hline 1 & Density at $40^{\circ} \mathrm{C}(\mathrm{kg} / \mathrm{m} 3)$ & $850-890$ \\
\hline 2 & Kinematic Viscosity at $40{ }^{\circ} \mathrm{C}(\mathrm{cSt})$ & $2.3-6.0$ \\
\hline 3 & Acid Number $(\mathrm{mg}-\mathrm{KOH} / \mathrm{g})$ & $\max 0.5$ \\
\hline 4 & $\begin{array}{c}\text { Oxidation stability } \\
\text { Induction period of the rancimat method (minutes) }\end{array}$ & 480 \\
\hline 5 & Induction period of the petroxy method (minutes) & 360 \\
\hline 5 & Water and Sediment $(\%$-vol) & $\max 0.05$ \\
\hline 6 & Methyl Ester Content $(\%$-mass $)$ & $\min 51$ \\
\hline 7 & Cetane Numbers & 100 \\
\hline 8 & Flash Point $\left({ }^{\circ} \mathrm{C}\right)$ & max 18 \\
\hline 9 & Cloud Point $\left({ }^{\circ} \mathrm{C}\right)$ & mumber 1 \\
\hline 10 & Copper Plate Corrosion $\left(3 \mathrm{~h}\right.$ at $\left.50{ }^{\circ} \mathrm{C}\right)$ & max 0.05 \\
\hline 11 & Carbon Residue In per original sample in $10 \%$ & distillation dregs $(\%$-mass $)$ \\
\hline 12 & Distillation Temperature $90 \%\left({ }^{\circ} \mathrm{C}\right)$ &
\end{tabular}




\section{METHODS}

In preparing the literature study, several stages were carried out. The stages taken are collection of journal articles, separation and analysis of journal articles, as well as the formulation of discussions and conclusions. The sequence of stages in the preparation of this literature study can be seen in Figure 1.



Figure 3. Flowchart of Method

\subsection{Collecting Journal Articles}

At this stage, journal articles are collected to determine the topic and identify problems that are the topics of discussion in the literature study conducted. This stage was carried out so that the objectives of this literature study coud be achieved, namely knowing the method of making biodiesel, the effect of using heterogeneous catalysts, and the optimum operating conditions in making biodiesel from Moringa seed oil. Sources of journal articles are obtained from Science Direct, Springer Publisher, Google Scholar and Emerald Publisher

\subsection{Journal Article Selection and Analysis}

This stage was carried out to obtain articles that match the topics of discussion. The article selection process begins with a search for journal articles on the manufacture of biodiesel from Moringa seed oil, then separates the articles based on catalysts used, effect of operating parameters, and biodiesel characteristics.

\subsection{Data Processing and Review Observation}


At the data processing stage, data collection was carried out from the articles collected, then the review was carried out regarding the topics studied. Research results from various researchers are grouped and then studied in full and in-depth in order to obtain appropriate detailed discussion. Biodiesel obtained from Moringa seed oil, was then compared with the biodiesel standards in accordance with SNI 7182: 2015, ASTM D6751 and EN 14214.

\section{RESULT AND DISCUSSION}

From the search and analysis results, it was obtained 41 journal articles related to objectives of this literature study. There were 24 main journal articles that discuss making biodiesel from Moringa seed oil. Of the 24 journal articles, 19 journal articles were selected that fulfilled the focus topics of this literature study. The process of making biodiesel from Moringa seed oil is carried out through the stages of extracting oil from Moringa seeds then followed by reacting the oil and methanol with the help of an acid or alkaline catalyst to produce biodiesel. From several research journal articles, the process of making biodiesel from Moringa seed oil is explained as follows.

\subsection{Extraction of Moringa Oleifera Seeds Oil}

The extraction of oil from Moringa seeds generally uses the soxhlet extraction method with n-hexane as solvent. Before the extraction process is carried out, the Moringa seeds are peeled from the skin, dried and crushed to form a powder to facilitate the extraction process [12] [16]. The so-called extractor was then used to extract oil from moringa seeds using n-hexane solvent for 6 hours [17]. The separation of the oil from the solvent can be carried out using a rotary evaporator [17] or by using a simple distillation [18].

The yield of Moringa seed oil can vary from 25\% - 44\% depending on geographic location, soil type, climatic conditions and the extraction method used [19]. Oladipo and Betiku [20] performed extraction from Moringa seeds using different solvents such as hexane, ethyl acetate, and ethanol.

The results showed that the percentage of oil yield was higher when n-hexane was used as a solvent compared to ethyl acetate and ethanol solvents. The high yield obtained using the $n$-hexane solvent is due to its lower polarity and boiling point indices than ethyl acetate and ethanol, with an oil yield of $41.71 \%$ w [20].

\subsection{Moringa Oleifera Biodiesel Production}

Process of biodiesel production from Moringa seed oil is generally carried out by a transesterification process using a homogeneous alkaline or heterogeneous catalyst. The process with alkaline catalysts is fast, but in the process, it is influenced by free fatty acids in the oil or fat. Free fatty acids can react with alkaline catalysts to form soap and water which make it difficult to recover biodiesel, thereby reducing yield biodiesel and increasing production costs [21]. Therefore, if the free fatty acid content of Moringa seed oil exceeds 3\%, a process required pre-treatment in the form of esterification using an acid catalyst [12]. Atabani et al. [13] also stated that the esterification process is needed to reduce the acid level to below $4 \mathrm{mg} \mathrm{KOH} / \mathrm{g}$. The acid catalyst that is commonly used in the esterification process is $\mathrm{H}_{2} \mathrm{SO}_{4}$.

The alcohol that is generally used in the esterification or transesterification process is methanol. Apart from methanol, other alcohols commonly used are ethanol, butanol, propanol and iso propanol [22]. The use of methanol as a reactant is due to its cheap price, high quality [23], high reactivity when reacting with triglycerides because it has a short chain [19]. The transesterification process is carried out by heating the oil at a certain temperature. After reaching the specified temperature, the mixture of methanol and catalyst is added. The addition of the methanol-catalyst solution is counted as the first time the reaction begins. When the reaction reaches the predetermined reaction time, heating and stirring are stopped [24] [25]. The reaction product is cooled and separated in a separating funnel for one night, to form two layers in the form of an upper phase containing the Moringa seed oil methyl 
ester (biodiesel) and the lower phase in the form of glycerol, methanol residue, catalyst, and unreacted triglycerides [26].

The separated methyl esters need to be purified to improve the quality of biodiesel. Most researchers use the water washing method or washing biodiesel with deionized water in the purification process. The washed biodiesel is put into a rotary evaporator to remove water and methanol contents [13], then dried using $\mathrm{Na}_{2} \mathrm{SO}_{4}$ followed by a filtration process [26]. There are also researchers who use the dry washing method in the purification process. Nurdyaningrum and Nasrudin [27] conduct Moringa seed oil biodiesel purification method by washing and cleaning using an activated bentonite adsorbent. The product of Moringa seed oil biodiesel refined has a lighter color, clearer, and transparent [27].

\subsection{Heterogeneous Catalyst in Biodiesel Production from Moringa Seed Oil}

The results of research from several researchers using heterogeneous catalysts are shown in Table 2 .

Tabel 2. The uses of heterogeneous catalyst

\begin{tabular}{cccc}
\hline No & Catalyst & Yield $(\%)$ & Reference \\
\hline 1 & $\mathrm{MgO}$ Nano Catalyst & 93.69 & {$[29]$} \\
\hline 2 & $\mathrm{MgO} \mathrm{Solid}$ & 60 & {$[4]$} \\
\hline 3 & $\mathrm{CaO}$ & 96 & {$[22]$} \\
\hline 4 & $\mathrm{SO}^{2-} / \mathrm{SnO}_{2}-\mathrm{SiO}_{2}$ & 84 & {$[9]$} \\
\hline 5 & $\mathrm{CuO}-\mathrm{CaO}$ & 95.24 & {$[3]$} \\
\hline 6 & $\mathrm{Conch} \mathrm{Shell}$ & 97.06 & {$[23]$} \\
& Egg Shell & 40 & {$[30]$} \\
7 & $\mathrm{CaO}$ & 13 & \\
& $\mathrm{KF} / \mathrm{CaO} 25 \% \mathrm{w}$ & 10 & \\
& $\mathrm{KF} /$ Egg Shell $25 \% \mathrm{w}$ & 63 & \\
& $\mathrm{KF} /$ Egg Shell 1\%w & 94.2 & \\
\hline
\end{tabular}

Esmaeili et al. [16] carried out the manufacture of biodiesel from Moringa seeds using nano $\mathrm{MgO}$ catalyst. The nano $\mathrm{MgO}$ catalyst has a very small size and the surface of the catalyst has a large number of pores, which is useful for the transesterification process. The specific surface area of the catalyst increases with the increasing number of pores in the catalyst. The transesterification process occurs on the surface of the catalyst. This is consistent with the research conducted by Nawi [23] which states that the catalytic activity depends on the surface area of the catalyst. The larger the surface area of the catalyst, the higher the catalytic activity is obtained. The greatest yield resulting from the research of Esmaeili et al. [16] is 93.69\%, which is greater than the Nawi study [23] which used solid $\mathrm{MgO}$ catalyst, with a yield of $60 \%$.

Niju et al. [28] made biodiesel from Moringa seed oil using a $\mathrm{CuO}-\mathrm{CaO}$ catalyst. The results of their research state that the $\mathrm{CuO}-\mathrm{CaO}$ catalyst has a high level of porosity, can be reused and its effectiveness is still high after five trials in the transesterification process. The results of Niju et al. [28] stated that the yield produced was still above 90\%, but after the fifth experiment the yield decreased significantly because of the strong catalyst also decreased. $\mathrm{CuO}-\mathrm{CaO}$ catalyst is also able to reduce the problem of soap formation in the top layer of biodiesel caused by the use of a Ca-based catalyst. Esterification and transesterification reactions can occur simultaneously without the formation of soap using heterogeneous catalysts, such as investigated by Kafuku et al. [9] using a tin oxide sulfate catalyst refined with $\mathrm{SiO}_{2}$.

The manufacture of biodiesel from Moringa seed oil can also be made with a heterogeneous catalyst that utilizes eggshell and shellfish waste, by first doing the calcination process. After the calcination process, the catalyst particle size will decrease, thus increasing the catalyst surface area [3]. The yield of biodiesel obtained using a shellfish catalyst is $97.06 \%$, which is quite high in biodiesel production 
Aziz et al. [30] compared the use of catalysts from eggshell impregnated with potassium fluoride (KF /eggshell), eggshell, commercial $\mathrm{CaO}$, and commercial $\mathrm{CaO}$ impregnated with potassium fluoride (KF $/ \mathrm{CaO}$ ). As a result, commercial $\mathrm{KF} / \mathrm{CaO}$ catalysts have a larger surface area than $\mathrm{KF} /$ eggshell catalysts. But the resulting biodiesel yield is greater using KF/egg shell catalysts. This is because the $\mathrm{CaO} / \mathrm{KF}$ catalyst occurs agglomeration of active $\mathrm{KCaF} 3$ crystals in $\mathrm{CaO}$, while the addition of $\mathrm{KF}$ to the eggshell increases the catalysis ability and prevents the saponification reaction from occurring. In addition, the high yield of biodiesel in $\mathrm{KF} /$ eggshells is caused by the good distribution of $\mathrm{KCaF}_{3}$ active crystals. When compared to the yield of biodiesel using eggshell catalysts with commercial $\mathrm{CaO}$ catalysts, the yield of biodiesel is greater using catalysts from eggshell waste. The results of this study indicate that the KF/eggshell catalyst is easy to make, economical and efficient in producing biodiesel from Moringa seed oil.

The use of heterogeneous catalysts in the manufacture of biodiesel from Moringa seed oil has promising potential. Apart from the relatively high yield of biodiesel (average higher than 90\%), the use of heterogeneous catalysts also facilitates the separation and purification process [9] [28]. Heterogeneous catalysts are low likely to cause corrosion, are environmentally friendly, and can be reused after the catalyst is filtered [28].

\subsection{Factors Affecting the Transesterification Process of Moringa Seed Oil}

In making biodiesel, there are variables that will affect the biodiesel conversion results. From literature research, it can be seen that the variables influencing the conversion results are the ratio of methanol to oil, type of catalyst, reaction temperature, reaction time, stirring speed and catalyst concentration. Esmaeili et al. [29] stated that the biodiesel yields increase with increasing molar ratio of oil and methanol. This is because increasing the methanol content will prevent methanol from reacting with a catalyst which causes difficulty in separating methanol from biodiesel and glycerin. In accordance with the stoichiometric reaction, excess methanol will also push the reaction to the right and increase the conversion, but the use of excess methanol with a long reaction time can cause a glycerolysis reaction [3] and increase the amount of energy when refining biodiesel [28]. The glycerolysis reaction causes glycerol to react with biodiesel to re-form monoglycerides instead of methyl esters [9].

Negative impacts will also arise if the use of methanol to oil ratio is too low. The use of low molar ratio of methanol and oil causes the reaction is not complete and it is difficult to separate methanol from biodiesel at the end of the process [30] [25]. The increase in the ratio of methanol and oil according to research by Kafuku et al. [9] does not have a major impact on biodiesel conversion. Research by Niju et al. [19] stated that the ratio of methanol to oil is more influential in making biodiesel than reaction time. Research by Niju et al. [19] optimized the operating conditions and saw the effect of the parameters of the catalyst concentration, reaction time and the ratio of methanol oil to biodiesel yield. The result is that the catalyst concentration is the most influential parameter among other parameters [19]. Research by Rashid et al. [26] also stated that the parameters which have a strong influence on ester formation are the catalyst concentration and the methanol oil ratio.

Kafuku and Mbarawa [25] optimized the use of $\mathrm{KOH}$ catalyst concentration in making Moringa seed oil biodiesel. The results from their research showed that the biodiesel yield increased is directly proportional to the increase in catalyst concentration. When the catalyst concentration exceeds $1 \%$, namely $1.25 \%$ and $1.5 \%$ the yield decreases and does not produce a clear layer at the end of the deposition process. At $2 \%$ and $2.5 \%$ catalyst concentrations no yield is observed. Dominguez et al. [16] also stated that the use of a catalyst that exceeds its optimum conditions can cause the conversion of biodiesel to decrease and does not produce a clear layer on deposition, and when washing using warm deionized water results in the formation of more soap. This is because the excess catalyst will cause the saponification reaction. The effect of the interaction between the catalyst concentration and the methanol oil ratio on yield biodiesel has been observed by Niju et al. [3]. The result is that at low oil methanol ratios, biodiesel conversion increases with increasing catalyst concentration to some extent and biodiesel yield decreases when the concentration is increased over $8 \% \mathrm{w}$. This is because the viscosity of the reaction mixture increases which increases the mass transfer resistance. 
Other parameters that affect the yield of biodiesel are temperature and reaction time. The high temperature results in the solubility of methanol in the oil and the number of effective collisions increases so that it will increase the efficiency of making biodiesel [16] [22].

Negative effects can also be generated if the operating temperature is too high. High temperatures can cause an increase in the saponification reaction of triglycerides, besides that at high temperatures it will also cause methanol to evaporate and reduce the contact between methanol and oil and catalyst [16] as well as high energy consumption [31]. When the temperature is low and the reaction time is short, the resulting biodiesel will be lower than the low temperature and long reaction time [9]. This is because the short reaction time will not be able to complete the reaction especially if the operating temperature is low. In contrast to the reaction temperature, if the reaction temperature increases the yield of biodiesel is almost the same even for a short or long reaction time [9]. According to Rashid et al. [26] there is no significant interaction between reaction temperature and time parameters on biodiesel yield.

Extending the reaction time will increase the yield of biodiesel due to mass transfer between the catalyst and methanol and stable oil [3]. Aziz et al. [30] performed an optimization of the transesterification reaction time from 1-3 hours with a methanol molar ratio of $6: 1$, a reaction temperature of $50{ }^{\circ} \mathrm{C}$, and a catalyst concentration of $5 \% \mathrm{w}$. The result is that the optimum reaction time occurs at 1 hour reaction time. When the reaction lasts more than 1 hour it causes soap to form due to hydrolysis of esters which causes more fatty acids to form soap. The biodiesel results from the research of Silva et al. [32] is not too big, namely less than $25 \%$ when using an $\mathrm{H}_{2} \mathrm{SO}_{4}$ catalyst and a reaction time of 480 minutes and $70 \%$ when using a $\mathrm{NaOH}$ catalyst and a reaction time of 240 minutes. Kafuku and Mbarawa [25] and Aziz et al. [30] agree that the best reaction time in the formation of Moringa seed oil biodiesel is 1 hour.

Several groups of researchers such as Kafuku et al. [9] Rashid et al. [8] and Niju et al. [28] do not mention that the speed of mixing has a big impact on the formation of biodiesel. According to Dominguez et al. [16], the rate of stirring is an important parameter at the start of the reaction. This is because the reactant/catalyst and oil are two liquids that do not dissolve each other. When the oil and reactant/catalyst phases have mixed and the reaction has started, the intensity of stirring is no longer needed, unless using a heterogeneous catalyst. The mixing speed that is too low causes the duration of the phase change, while the very high stirring speed will also cause soap to form. Therefore, high stirring intensity requires a shorter reaction period [25].

\subsection{Moringa Oleifera Biodiesel Characterization}

Characteristics of Moringa seed oil biodiesel from several studies compared with international standards (ASTM D6751 and EN 14214) and national standards (SNI 7182: 2015) are shown in Table 3. Variation in characteristic values can be caused by differences in production techniques and reaction conditions [21]. Overall, the value of each characteristic parameter of Moringa seed oil biodiesel is in accordance with international and national standards. According to Kivevele, et al. [33] the most striking characteristic value of Moringa seed oil biodiesel is its high cetane value, which is above 60. This is also mentioned by Miskah et al. [33] that the cetane number of Moringa seed oil biodiesel is higher when compared to diesel, which is at least 51 . The higher the cetane number, the faster the fuel ignition process occurs and it accelerates the combustion which has an impact on reducing exhaust emissions [35]. If the value of cetane number is low, it will cause high pressure which will cause an explosion in the combustion chamber followed by denotation [36].

The flash point value of Moringa seed oil biodiesel is in accordance with international and national standards, its value is also higher than diesel fuel which has a flash point of $68{ }^{\circ} \mathrm{C}$. This flash point is related to the safety of fuel storage and transportation [16]. The flash point states the lowest temperature in biodiesel fuel which will cause instantaneous ignition if a spark is present [16]. 
The smallest observed value of oxidation stability is obtained in the study of Rashid et al. [26] of 3.52 hours and the highest value in the study of Fernandes et al. [17] totaling 19.3 hours. The value of oxidation stability in the study of Rashid et al. [26] referring to ASTM D6751, it is still included in the required standards, whereas if it refers to SNI 7182: 2015 and EN 14214 it has not entered into the standard. The low value of oxidation stability is due to the fact that the natural antioxidants present in Moringa seed oil have been deactivated by the refining or separation process during the manufacture of biodiesel [33]. To overcome this problem, it requires the use of antioxidants to meet the standard requirements for biodiesel [13].

Table 3. Characteristics of moringa seed oil biodiesel

\begin{tabular}{|c|c|c|c|c|c|c|c|c|c|c|c|c|}
\hline \multirow[t]{2}{*}{ No } & \multirow[t]{2}{*}{ Properties } & \multicolumn{8}{|c|}{ Reference } & \multirow[t]{2}{*}{$\begin{array}{l}\text { ASTM } \\
\text { D6751 }\end{array}$} & \multirow[t]{2}{*}{$\begin{array}{l}\text { EN } \\
14214\end{array}$} & \multirow[t]{2}{*}{$\begin{array}{l}\text { SNI } \\
7182: \\
2015 \\
\end{array}$} \\
\hline & & {$[26]$} & [25] & [33] & [13] & [37] & [38] & [9] & [28] & & & \\
\hline 1 & $\begin{array}{l}\text { Flash Point } \\
\left({ }^{\circ} \mathrm{C}\right)\end{array}$ & $\begin{array}{l}162 \\
\pm 3\end{array}$ & 206 & 166 & 176 & 176.5 & 180.5 & 206 & 140 & $\begin{array}{l}\text { Min. } \\
130\end{array}$ & Min.120 & $\begin{array}{l}\text { Min.10 } \\
0\end{array}$ \\
\hline 2 & $\begin{array}{l}\text { Pour Point } \\
\left({ }^{\circ} \mathrm{C}\right)\end{array}$ & $\begin{array}{l}17.0 \\
0 \pm \\
0.14 \\
\end{array}$ & 3 & 3 & 19 & -1 & 19 & 3 & -10 & - & - &  \\
\hline 3 & $\begin{array}{l}\text { Cloud } \\
\text { Point }\left({ }^{\circ} \mathrm{C}\right)\end{array}$ & $\begin{array}{l}18.0 \\
0 \pm \\
0.12 \\
\end{array}$ & 10 & 10 & 21 & 0 & 19 & 10 & -13 & $\begin{array}{l}\text { Max. } \\
18^{\circ} \mathrm{C}\end{array}$ & - & $\begin{array}{l}\text { Max. } \\
18^{\circ} \mathrm{C}\end{array}$ \\
\hline 4 & $\begin{array}{l}\text { Density } \\
\left(\mathrm{Kg} / \mathrm{m}^{3}\right)\end{array}$ & $\begin{array}{l}875 \\
\pm \\
15.7 \\
\mathrm{a}\end{array}$ & $\begin{array}{l}877.5 \\
\text { B }\end{array}$ & $890^{\mathrm{b}}$ & $\begin{array}{l}0.86 \\
\mathrm{c}\end{array}$ & $876.1^{\mathrm{d}}$ & 859.6 & $877.5^{\mathrm{b}}$ & $0.87^{\mathrm{c}}$ & $\begin{array}{l}870- \\
900\end{array}$ & $860-900$ & $\begin{array}{l}850- \\
890\end{array}$ \\
\hline 5 & $\begin{array}{l}\text { Kinematic } \\
\text { Viscosity } \\
(\mathrm{cSt})\end{array}$ & $\begin{array}{l}4.80 \\
\pm \\
0.04 \\
\end{array}$ & 4.91 & 4.78 & 5.07 & 4.126 & 5.05 & 4.91 & 4.6 & $1.9-6.0$ & $3.5-5.0$ & $2.3-6$ \\
\hline 6 & $\begin{array}{l}\text { Acid Value } \\
(\mathrm{mg} \\
\mathrm{KOH} / \mathrm{g})\end{array}$ & $\begin{array}{l}0.38 \\
\pm \\
0.03 \\
\end{array}$ & 0.012 & - & - & - & - & 0.012 & 0.2 & 0.5 & 0.5 & $\begin{array}{l}\text { Max. } \\
0.5\end{array}$ \\
\hline 7 & $\begin{array}{l}\text { Cetane } \\
\text { Number } \\
\end{array}$ & $\begin{array}{l}67 \pm \\
1.52 \\
\end{array}$ & 62.12 & 63 & - & - & 56 & 62.12 & 48.2 & $\begin{array}{l}\text { Min. } \\
47 \\
\end{array}$ & Min. 51 & Min.51 \\
\hline 8 & $\begin{array}{l}\text { Oxidative } \\
\text { Stability } \\
\text { (h) }\end{array}$ & $\begin{array}{l}3.52 \\
\pm \\
0.12 \\
\end{array}$ & - & $\begin{array}{l}5.05 \\
\mathrm{e}\end{array}$ & $e^{12.6}$ & 12.64 & - & - & - & Min. 3 & Min. 6 & Min. 8 \\
\hline 9 & $\begin{array}{l}\mathrm{HHV} \\
(\mathrm{mJ} / \mathrm{kg})\end{array}$ & $\begin{array}{l}45.2 \\
8 \pm \\
0.98\end{array}$ & - & 38.3 & - & 39.89 & - & - & 41.58 & - & - & - \\
\hline
\end{tabular}

The pour point and fog point values of Moringa seed oil biodiesel are higher than diesel fuel. This makes the use of biodiesel unsuitable when it is used in cold climates because it will interfere with engine performance [16]. The use of biodiesel in tropical areas, such as in Indonesia, is suitable because of its high rate of consumption and low exhaust emissions.

Characteristics of Moringa seed oil biodiesel from several researchers who state that they have met national and international standards are shown in Table 4.

Table 4. Characteristic of moringa seed oil biodiesel that meet national and international standard 


\begin{tabular}{|c|c|c|c|c|c|c|c|c|c|c|c|c|}
\hline \multirow{2}{*}{$\begin{array}{c}\mathbf{N} \\
\mathbf{o}\end{array}$} & \multirow[b]{2}{*}{ Properties } & \multicolumn{8}{|c|}{ References } & \multirow{2}{*}{$\begin{array}{l}\text { ASTM } \\
\text { D6751 }\end{array}$} & \multirow{2}{*}{$\begin{array}{c}\text { EN } \\
14214\end{array}$} & \multirow{2}{*}{$\begin{array}{c}\text { SNI } \\
7182: \\
2015 \\
\end{array}$} \\
\hline & & [8] & [39] & [40] & [6] & [32] & [34] & [25] & [35] & & & \\
\hline 1 & $\begin{array}{c}\text { Flash Point } \\
\left({ }^{\circ} \mathrm{C}\right)\end{array}$ & $\begin{array}{l}162 \\
\pm 3\end{array}$ & 206 & 166 & 176 & 176.5 & 180.5 & 206 & 140 & $\begin{array}{c}\text { Min. } \\
130\end{array}$ & $\begin{array}{c}\text { Min. } \\
120\end{array}$ & Min. 100 \\
\hline 2 & $\begin{array}{c}\text { Kinematic } \\
\text { Viscosity } \\
(\mathrm{cSt}) \\
\end{array}$ & $\begin{array}{c}4.80 \\
\pm \\
0.04 \\
\end{array}$ & 4.91 & 4.78 & 5.07 & 4.126 & 5.05 & 4.91 & 4.6 & $1.9-6.0$ & $3.5-5.0$ & $2.3-6$ \\
\hline 3 & $\begin{array}{c}\text { Density } \\
(\mathrm{Kg} / \mathrm{m} 3)\end{array}$ & $\begin{array}{c}875 \\
\pm \\
15.7 \\
\mathrm{a}\end{array}$ & $877 .^{\mathrm{b}}$ & $890^{\mathrm{b}}$ & $0.86^{\mathrm{c}}$ & $876.1^{\mathrm{d}}$ & 859.6 & $877.5^{\mathrm{b}}$ & $0.87^{c}$ & $\begin{array}{l}870- \\
900\end{array}$ & $\begin{array}{l}860- \\
900\end{array}$ & $850-890$ \\
\hline 4 & $\begin{array}{c}\text { Cetane } \\
\text { Number }\end{array}$ & $\begin{array}{l}67 \pm \\
1.52 \\
\end{array}$ & $\begin{array}{c}62.1 \\
2 \\
\end{array}$ & 63 & - & - & 56 & 62.12 & - & $\begin{array}{c}\text { Min. } \\
47\end{array}$ & $\begin{array}{c}\text { Min. } \\
51\end{array}$ & Min.51 \\
\hline 5 & $\begin{array}{l}\text { Oxidative } \\
\text { Stability } \\
\text { (h) }\end{array}$ & $\begin{array}{c}3.52 \\
\pm \\
0.12\end{array}$ & - & $5.0^{\mathrm{e}}$ & $12 .^{\mathrm{e}}$ & 12.64 & - & - & - & Min. 3 & Min. 6 & Min. 8 \\
\hline
\end{tabular}

\section{CONCLUSION}

The extraction of oil from moringa seeds can be done using the soxhlet extraction method with nhexane as solvent. The transesterification process is the most common method used to produce biodiesel from Moringa seed oil. The most influential operating parameters in producing Moringa seed oil biodiesel are the molar ratio of methanol and oil, catalyst concentration, reaction time, and reaction temperature. The use of heterogeneous catalysts in the manufacture of Moringa seed oil biodiesel can produce an average yield of above $90 \%$. Moringa seed oil biodiesel has been tested for its feasibility according to SNI 7182: 2015, ASTM D5761 and EN 14214 so it is safe to use as fuel.

\section{ACKNOWLEDGMENT}

High appreciation is conveyed to Politeknik Negeri Bandung for supporting the funding of this literature study through the Student Creativity Program-Research 2020 No. 583/PL1.R3/ KM.08.03/2020.

\section{REFERENCES}

[1] Sartika, A., Nurhayati, \& Muhdarina. (2015). Esterifikasi Minyak Goreng Bekas dengan Katalis $\mathrm{H}_{2} \mathrm{SO}_{4}$ dan Transesterifikasi dengan Katalis CaO dari Cangkang Kerang Darah: Variasi Kondisi Esterifikasi . Volume 2. No.1

[2] Bahar, H., Saputra, E., \& Zultiniar. (2017). "Pembuatan Biodiesel Dari Minyak Biji Nyamplung Dengan Sintesis Katalis Basa $\mathrm{Na}_{2} \mathrm{SiO}_{3} / \mathrm{Fe}_{3} \mathrm{O}_{4}$ ". Jurnal FTEKNIK Volume 4 No. 2 .

[3] Niju, S., Anushya, C., \& Balajii, M. (2018). "Process Optimization for Biodiesel Production from Moringa oliefera Oil Using Conch Shells as Heterogeneous Catalyst".

[4] Nasir, S., Soraya, D. F., \& Pratiwi, D. (2010). "Pemanfaatan esktrak biji kelor (moringa oleifera) untuk pembuatan bahan bakar nabati". Jurnal Teknik Kimia no 3 vol 17.

[5] Aminah, Syarifah, Ramdhan, Tezar, \& Yanis. (2015). "Kandungan Nutrisi dan Sifat Fungsional Tanaman Kelor (Moringa Oleifera)". Balai Pengkajian Teknologi Pertanian Jakarta.

[6] Arini, K.R.D. (2015). "Pembuatan Biodiesel dari Mikroalga Chlorella Sp. Melalui Proses Esterifikasi dan Transesterifikasi”. Politeknik Negeri Sriwijaya

[7] Marchetti, J.M. and Errazu, A.F., (2008), Comparison of Different Heterogeneous Catalysts and Different Alcohols for The Etherification Reaction of Oleic.

[8] Rashid, U., Anwar, F., Moser, B. R., \& Knothe, G. (2008). “(Moringa oeifera) Oil: A Possible Source of Biodiesel". Bioresource Technology. 
[9] Kafuku, G., Lam, M. K., Kansedo, J., Lee, K. T., \& Mbarawa, M. (2010). "Heterogeneous Catalyzed Biodiesel Production from Moringa oleifera Oil. Fuel Processing Technology".

[10] Prayanto, D. S., \& Salahudin, M. (2016). Pembuatan Biodiesel dari Minyak Kelapa dengan Katalis $\mathrm{NaOH}$ Menggunakan Gelombang Mikro (Microwave) secara Kontinyu.

[11] Aziz, I., Nurbaya, S., \& Ulum, B. (2011). "Pembuatan Produk Biodiesel dari Minyak Goreng Bekas dengan Cara Esterifikasi dan Transesterifikasi". Valensi 2 (3) : 443-448.

[12] Oyinade, A. T. \& Damilare, A. S. (2020). "Production and Characterization of Biodiesel from Moringa olifera Seed Oil Using Alkaline Catalyst". Volume 5, Issue 2.

[13] Atabani, A., Mahlia, T., Masjuki, H., Badruddin, I. A., Yussof, H. W., Chong, W., \& Lee, K. T. (2013). "A comparative Evaluation of Physical and Chemical Properties of Biodiesel Synthesized from Edible and Non-edible Oils and Study on The Effect of Biodiesel Blending". Energy, 296 304.

[14] Hikmah, M. N. \& Zuliyana. (2010). "Pembuatan Metil Ester (Biodiesel) dari Minyak Dedak dan Methanol dengan Proses Esterifikasi dan Transesterifikasi. Skripsi".

[15] Helwani, Z., Othman, M. R., Aziz, N., Kim, J., \& Fernando, W. (2009). "Solid Heterogeneous Catalyst for Transesterification of Triglycerides with Methanol". Applied Catalysis A 363, 1-10.

[16] Domínguez, Y. D., García, D. T., Pérez, L. G., Fernández-Santana, E., Macias, M. R., Fischer, T., \& Piloto-Rodríguez, R. (2019 ). "Rheological behavior and Properties of Biodiesel and Vegetable Oil from Moringa oleifera Lam”.

[17] Fernandes, D. M., Sousa, R. M., Oliveira, A. d., Morais, S. A., \& Richter, E. M. (2015). Fuel. "Moringa oleifera: A Potential Source for Production of Biodiesel".

[18] Garba, A., Medudu, D., Gwaski, P., \& Amusat, R. (2015). "Extraction and Characterization of Moringa oleifera Seed Oil".

[19] Niju, S ${ }^{\text {. }}$, Fernando Russella Raj, C. A., \& Balajii, M. (2019). "Optimization of Acid Catalyzed Esterification and Mixed Metal Oxide Catalyzed Transesterification for Biodiesel Production from Moringa oliefera Oil”. Green Process Synth , 8: 756-775.

[20] Oladipo, B. \& Betiku, E. (2019). Process Optimization of Solvent Extraction of Seed Oil from Moringa Oleifera : An Appraisal of Quantitive and Qualitative Process Variables on Oil Quality Using D-Optimal Design. Biocatalysis and Agricultural Biotechnology, 1-12

[21] Omonhinmin, C., Olomukoro, E., Ayoola, A., \& Egwim, E. (2020). "Utilization of Moringa oleifera Oil for Biodiesel Production: A Systematic Review".

[22] Zubairu, A. \& Ibrahim, F. S. (2014). "Moringa oleifera Oil Seed as Viable Feedstock for Biodiesel Production in Northern Nigeria". 4(2): 21-25.

[23] Nawi, A. B. (2015). "Biodiesel Production from Moringa oliefera Seeds Oil Using MgO AS A Catalyst". Faculty of Chemical \& Natural Resources Engineering: Universitas Malaysia Pahang.

[24] Mukhtar, M. \& Zubairu, A. Y. (2016). "Biodiesel Production from Moringa oleifera Seed Oil using $\mathrm{MgO} / \mathrm{Al} 2 \mathrm{O} 3$ Catalyst. IJSGS", 2(3).

[25] Kafuku, G. \& Mbarawa, M. (2010). Alkaline Catalyzed Biodiesel Production from Moringa oleifera Oil. Applied Energy .

[26] Rashid, U., Anwar, F., Ashraf, M., Saleem, M., \& Yusup, S. (2011). "Application of Response Surface Methodology for Optimizing Transesterification of Moringa oliefera Oil: Biodiesel Production". Energy Conversion and Management.

[27] Nurdyaningrum, F. D. \& Nasrudin, H. (2013). "Pemurnian dan Karakterisasi Biodiesel dari Minyak Biji Kelor (Moringa Oleifera) dengan menggunakan Adsorben Bentonit". UNESA Journal of Chemistry Vol.2.

[28] Niju, Sa., Balajii, M., \& Anushya, C. (2019). "International Journal of Green Energy."A comprehensive review on biodiesel production", VOL. 16, NO. 9, 702-715.

[29] Esmaeili, H., Yeganeh, G., \& Esmaeilzadeh, F. (2019). "Optimization of Biodiesel Production from Moringa oleifera Seeds Oil in The Presence of Nano-MgO using Taguchi Method". 
[30] Aziz, M., Triwahyono, S., Jalil, A., Rapai, H., \& Atabani, A. (2016). Transesterification of Moringa oleifera Oil to Biodiesel Over Potassium Flouride", 22-26.

[31] Abdullah, Savitri, A., \& Irwan, A. (2017). "Pengaruh Temperatur dan Waktu Reaksi Pada Karakteristik Biodiesel Hasil Transesterifikasi Minyak Sawit dengan Sistem Pelarut Petroleum Benzin”. Sains dan Terapan Kimia, Vol. 11 No.1 Hal 37-44.

[32] Silva,J. P., Serra, T. M., Gossmann, M., Wolf, C. R., Meneghetti, M. R., \& Meneghetti, S. M. (2010). "Moringa oleifera Oil: Studies of Characterization and Biodiesel Production". Biomassa and Energy.

[33] Kivevele, T. T., Mbarawa, M. M., Bereczky, A., \& Zoldy, M. (2011). "Evaluation of the Oxidation Stability of Biodiesel Produced from Moringa oliefera Oil". Energy and Fuels , 25, 5416-5421.

[34] Miskah, S., Anugrah, A., \& Gunadi. (2016). "Pemanfaatan Kulit Telur Sebagai Katalis Biodiesel dari Campuran Minyak Jelantah dan Minyak Kelapa Sawit”. No. 2, Vol. 22.

[35] Mofijur, M., Masjuki, H., Kalam, M., Rasul, M., Atabani, A., Hazrat, M., \& Mahmudul, H. (2015)." Effect of Biodiesel-Diesel Blending on Physico-Chemical Properties of Biodiesel produced from Moringa oleifera". 665-669.

[36] Warsita, A. (2012). "Pengaruh Injection Timing dan Prosentase Campuran Minyak Diesel dengan Bahan Bakar Biodiesel Terhadap Karakteristik Mesin dan Emisi Gas Buang". Vol. 12 No. 2.

[37] Wakil, M. A., Kalam, M. A., H. H., Fattah, I. M., \& Masum, B. (2014). "Evaluation of Rice bran, Sesame and Moringa Oils as Feasible Sources of Biodiesel and The Effect of Blending on Their Physicochemical Properties".

[38] Rashed, M.M., Kalam, M.A., Masjuki, H.H., Mofijur, M., Rasul, M.G. (2015). "Performance and emission characteristics of a diesel engine fueled with pal, jatropha and moringa oil methyl ester". Insudtrial Crops and Products.

[39] Kaddihani, W. (2015, april 1). Pojok Biodiesel.Dipetik maret 3, 2020, dari Balai Teknologi Bahan Bakar dan Rekayasa Disain: https://btbrd.bppt.go.id/index.php/services/26-pojok-biodiesel/94sni-biodiesel.

[40] Ketaren, S. (1986).’Pengantar Teknologi Minyak dan Lemak.” Jakarta: Universitas Indonesia. 